\title{
BLUE GUMS FORTRESS OBSERVATION POST SIMON'S BAY FIRE COMMAND 1942-1955
}

by Cdr W.M. Bisset*

The Second World War was the "finest hour" in the history of coast artillery in South Africa. It was a period of hectic activity and phenomenal growth but it was also, fortunately, a great anticlimax because South Africa was spared an attack on her coastal cities and towns by enemy warships and aircraft.

A recent request for information about one of the many coast artillery buildings erected in South Africa during the Second World War revealed that relatively little information about it could be found in the SADF Archives. When the file on this topic was discovered in a tin trunk containing old files at Fort Wynyard recently, the lack of information in Pretoria became easier to understand!

Blue Gums Fortress Observation Post is 400 feet above mean sea level on the mountainside between Miller's Point and Smitswinkel Bay. It is above the house Blue Gums which was the home of the Revd Leonard Green, an Anglican RN Chaplain.

Although the date when Blue Gums Fortress Observation Post was built has not been traced it seems likely that it was completed in 1942. It was one of six Fortress Observation Posts in the Simon's Bay Fire Command. Cobra at Slangkop, Bosch at Olifantsbosch and Vasco at Cape Point covered their respective water areas on the Atlantic side of the Peninsula, while Diaz at Cape Point, Crow at Scala and Blue Gums did so on the False Bay side.

The Historical Record of 2nd Heavy Battery, S.A. Artillery (a misleading term as it was really the regiment manning all the batteries in the Simon's Bay Fire Command) reveals that the Fortress Observation Posts at Cape Point, Olifantsbosch and Slangkop were in action by the middle of 1941.

On 10 June 1942 proposals regarding an agreement with Mr A.H. Day and his partner for the construction of an access road from the Marine Drive to the mountain-side site of the Fortress Observation Post at Blue Gums were submitted to the Quartermaster-General for approval. The terms of the agreement provided that the right of way should be granted for the duration of the Second World War and twelve months thereafter but should not exceed nine years and eleven months.

A very thorough investigation carried out in June 1956 revealed that the available documents confirmed that Mr Day was the owner of the property on which the F.O.P had been built.

In a letter dated 21 July 1942 the General Staff Officer I at the Castle requested that accommodation for one White NCO and 20 members of 1 Battalion, Native Military Corps be provided at Blue Gums. Ten days later the Fortress Commander submitted the request to the Quartermaster-General and advised him that the Director of Fortifications and Coastal Works had been requested to prepare plans and an estimate of costs. He added that the acquisition of sites was being investigated by Major Halse of the office of the Secretary for Defence.

Drawing Number QF 2024/2 dated December 1944 which illustrates this article, indicates that the F.O.P was a concrete structure and that the kitchen and mess were housed in the same wooden building. Between the two were wooden ablutions and an iron water tank. (This plan was copied in September 1954 by WOI C.E. Allen of the SA Corps of Marines).

A kitchen was requested on 9 February 1943 but was only Priority A (ie "works which can fall away"). It is not clear whether the kitchen requested was a separate building which was never built or whether the mess was altered to include the kitchen.

The most important item of equipment at the F.O.P was a Fortress Position Finder " $Y$ " Mk 1 which had a maximum range of 28000 yards. Target data was transmitted by telephone through the rangefinding exchange. 


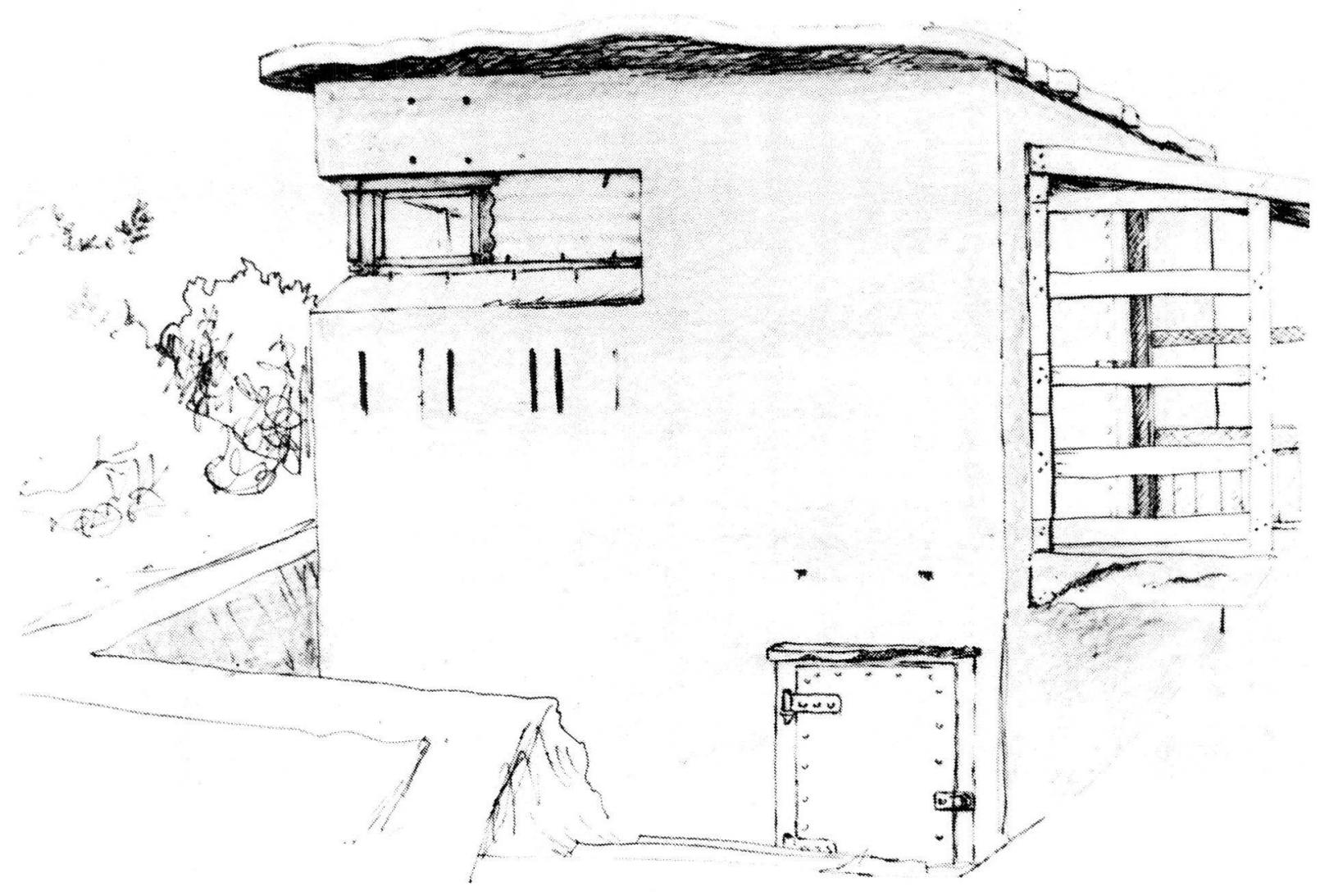

Blue Gums Fortress Observation Post Simon's Bay Fire Command. (Drawing by Mr A.N. Dromas)

After the Allied victory in North Africa it became clear that the danger of an enemy attack was greatly reduced. In January 1944 Vasco and Cobra F.O.P's were closed down due to shortage of personnel.

On 13 June 1947 two ex-servicemen, who had served in the SA Air Force, applied in writing to the Secretary of the War Stores Disposal Board in Pretoria to "acquire the use of the complete block" at the Blue Gums F.O.P. They had paid several visits to Cape Point and inspected a small, deserted U.D.F hut. Despite its delapidated state they considered it ideal as a headquarters for their weekend fishing trips.

Their letter contains a description of the buildings: "a small concrete blockhouse, a woodshed, a water tank and a latrine adjoining it". The buildings were numbered from $\mathrm{T} 1$ to $\mathrm{T} 5$. However, on 13 September 1947 the Acting Officer Commanding Cape Command advised the Quartermaster-General that the hutments of Blue Gums F.O.P were still required.
On 20 December 1948 the Administration Officer of Coastal Works and Fortifications inspected Blue Gums F.O.P and submitted a report to the Officer Commanding Cape Command the following day. He reported that there were no boundary stones or beacons indicating the extent of the property. He added that the security fence was in excellent condition and that the buildings were in fair condition. The F.O.P was very well kept and everything was found in good order. There was no caretaker.

On 5 September 1949 Brigadier Zinn, the Acting Quartermaster-General advised the Officer Commanding Cape Command in writing that the application to spend £3.15/- on repainting the number plates on all buildings at Blue Gums F.O.P had not been approved because of "the need for drastic curtailment of expenditure".

By 30 June 1950 it had become necessary to remove the stove, sink and washbasin from buildings $\mathrm{T} 2$ and $\mathrm{T} 4$ because hooligans had tampered with the stove. The Public Works De- 
partment estimated that the work would cost £5. Although permission was granted for the items to be removed and handed over to the Public Works Department for safekeeping, the Officer Commanding Cape Command informed the Officer Commanding 2 Coast Regiment (formerly 2 Heavy Battery) that one of his artisans must do this work.

The wartime agreement was due to expire on 27 May 1953 , so the Secretary for Defence timeously requested the Quartermaster-General to advise him whether it should be extended. On 1 August 1952 the Officer Commanding Coastal Command advised the Quartermaster-General and Naval and Marine Chief of Staff that Blue Gums still formed "a link in the general framework of the Simonstown defences" an that it was essential that the road be retained. He requested that "negotiation should be opened in order to secure occupation for a further period of 10 years".

Coast Artillery became absolete in South Africa in 1955 and resulted in the disbandendment of the SA Corps of Marines on 1 October 1955.

Thus on 31 December 1956 the Naval Chief of Staff advised the Quartermaster-General that Blue Gums F.O.P. was, 'no longer a requirement for coast artillery and did not justify the purchase of the site'. The site and F.O.P. were to be returned to Mr Day.

${ }^{*}$ Cdr W.M. Bisset is S0 1 SADF Museum Service.

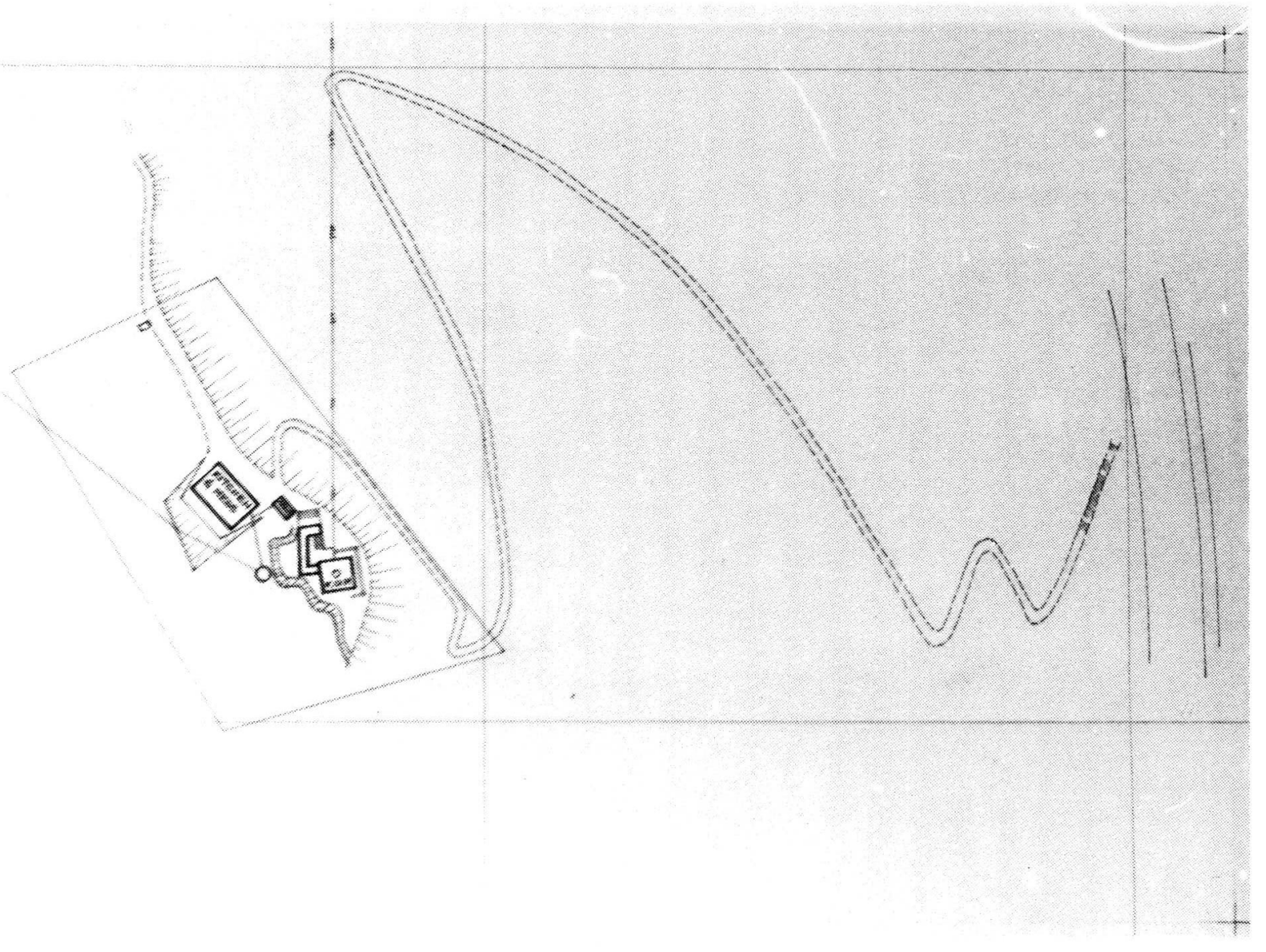

Blue Gums Fortress Observation Post Cape Point Simon's Town Fire Command, World War II 